\title{
"A Culture of the People": Politics and Working-Class Literature in Left Review, 1934-38
}

\section{Ronald Paul}

In the editorial published as part of the final issue of Left Review in May 1938, an attempt was made at summing up the cultural achievement of the journal during the four years of its existence. Written in the shadow of the world war that loomed ahead, much of what is said refers to the active political contribution made to the struggle against Fascism. However, in a more utopian mode, the editors also recalled that from its inception the journal consistently argued that one of the most effective democratic bulwarks against any reactionary dictatorship would be the creation of a genuine people's culture. This was the ideological pivot around which both the cultural and political aims of the journal were always seen to revolve. Thus, referring specifically to the revolutionary manifesto drawn up by the British Section of the Writers' International - principles on which Left Review was originally founded - the editorial reiterated that "a culture can only make itself safe from Fascist destruction which has rooted itself in the life of the people, which has become something which people know they cannot do without."1

One of the most palpable ways in which this ambition to promote "a true social culture" 2 was expressed was through the conscious efforts of the editors over the years to encourage working-class writing in the pages of the journal. This was done partly by inviting already established British working-class novelists like James Hanley, Ralph Bates, John Sommerfield, Harold Heslop and others to contribute to the journal. Another important means of activating newer working-class literary talent was in the series of "Readers' Competitions," which were advertised regularly in the journal. Amateur writers, it was hoped, would have their work selected and appear in print - often for the very first time - together with comments by the editors. It is this particular aspect of the journal's critical work which I wish to explore here. The aim is, however, not merely to try and recover a relatively neglected aspect of radical periodical history in Britain. By looking closer at the process of eliciting and evaluating such readers' contributions, the problematic relationship between politics and literature in the 1930s will be contextualized and hopefully illuminated in a more tangible way. Moreover, such a discussion has, I would claim, a bearing not only on the changing aesthetics and politics of Left Review itself, but remains relevant to the ongoing debate both about the need to reclaim the past literature of the left, as well as about the nature of working-class writing today. However, before looking in more detail at these literary competitions, it seems pertinent to examine briefly the way in which Left Review has itself been critically assessed over the years. Once again, the issue of literature and poli- 
tics looms large in this discussion, a question which is also intimately linked to the debate about the lasting cultural significance of the journal.

Since its demise as one of the leading radical journals of the 1930s, Left Review has received a mixed share of critical attention, much of which has been negative. Even at the time of its publication, several prominent writers were skeptical of its overtly political stance. George Orwell, for instance, wrote in The Road To Wigan Pier (1937) that not only was the sincerity of many of its Communist contributors "suspect," its pages were full of examples of the sort of "'proletarian' cant from which we now suffer." In his own, personally retrospective account of the period, The Thirties: A Dream Revolved (1960), Julian Symons also repeats the claim that politics had a devastating impact on the journal's aesthetics: "The chief criticism to be made of Left Review is that the effect of its conscious party line was to make its contributors write so uncommonly badly."4

Symons goes on to single out the titles of some of the contributions by working-class writers to the literary competitions as indicative in themselves of the level of "crude propaganda" in the pages of the journal..$^{5}$ Samuel Hynes, in what is regarded as the standard critical study (1976) of the relationship between literature and politics in the 1930s, plays downs the cultural importance of journal altogether. Comparing it very cursorily to its radical forerunner, Viewpoint, the pages of Left Review contained, according to Hynes, a "somewhat diminished" element of "individualism and metaphysics" in favour of "militant communism."" In a similarly depreciatory vein, Bernard Bergonzi refers only to the "simplistic, sentimental Russophilia" of the journal "where the sharpness of the anti-capitalist polemic is in striking contrast to the naivety of the pro-Soviet propaganda." Commenting on such disparaging responses to the journal, Adrian Caesar concludes in a more recent study (1991) that the "concern for, and encouragement of, working-class writing, together with the pro-Soviet, openly Marxist position of many of the contributors, has led to the magazine's been treated dismissively by liberal and conservative literary historians." 8 This rejection of the cultural and political values associated with the journal is, however, not an attitude shared exclusively by non-socialist intellectuals, as the above example of Orwell shows. In recent anthology of Marxist literary theory (1996), the editors, Terry Eagleton and Drew Milne, also remain deeply critical of those writers associated with Left Review whom they describe as a group "compromised by the cultural politics of Stalinism" who were later "hegemonically defeated by the more formally acute 'new' criticism."

However, in contrast, a growing number of other critics of Left Review have also tried to problematize this simplistic image of the journal as a mere mouthpiece of Stalinism deserving only to be relegated to the dustbin of cultural history. David Margolies for example refutes the charge of a journal completely blinkered by Stalinist theories of Socialist Realism, claiming that "in 
fact, writers in Left Review regularly attacked crude, mechanical, abstract responses to literature." 10 Valentine Cunningham is himself a case of a critic who seems to have radically revised his own views of the journal over the years. In an essay from 1980, he refers only cryptically to the journal's Communist "orthodoxy," 11 while more recently (1997), he states that at least during the first years of its existence, the journal reflected:

a busy to-and-fro of critical opinion about the nature of left-wing writing and the role of the left-wing writer. They were utterly characteristic of the aesthetico-theoretical disagreements the magazine aired. 12

In her discussion (1998) of the work of Sylvia Townsend Warner, a distinguished radical novelist and poet who was herself actively associated with Left Review in the 1930s, Maroula Joannou quotes Margot Heinemann in stating that the journal signified in fact an important transitional moment in the cultural work of the left, helping to define "the beginnings of a more open, historically-minded kind of Marxism - what we may now call Gramscian."13 Joannou herself also points out that in Left Review "women featured more prominently in its pages than in comparable publications of the time" and that the journal functioned as "an important forum in which writing for the "common people' was discussed." 14 Perhaps one of the most prescient of critical responses to the question of the journal's lasting historical value was made by the historian, E. P. Thompson, in his review of the 1968 reprint of the complete set of Left Review issues. Here Thompson refers in particular to the rich and varied cultural range of the journal which, he states, literary critics might fruitfully explore:

All this is much, and may come in the future to seem more, when readers are less oppressed by historical hindsight: when they are more ready to perceive the enlargement of sympathies and the originality of themes (as compared with any literary movement of the 1920s) and less sensitive to the blight laid upon this promise by the encroachment of doctrinal Stalinism within the review. 15

A further sign of this more positive, critical re-evaluation of the journal has been the publication in 1998 of a new anthology of Left Review material, which for the first time provides a broad selection of cultural contributions to it. In his introduction, David Margolies makes a compelling case for a fundamental reappraisal of the journal's radical aesthetic importance:

In its cultural production, Left Review made an enduring contribution to the development of Marxist literary criticism, theorizing the role and function of literature, presenting a more or less coherent explanation of literature as a social phenomenon, and raising questions about the nature of literature's social value that are still alive in discussion today. ${ }^{16}$

In an attempt to follow on from this more recent line of historical reinter- 
rogation of the critical issues raised in Left Review, I intend here to look more closely at one central question which was constantly debated throughout the whole existence of the journal - that of the link between politics and literature. More specifically I want to discuss how different editors of Left Review negotiated this question in its most practical form through the encouragement and assessment of literary contributions from working-class readers of the journal. It is in connection with the intermittently run "Readers' Competitions" that, I would claim, some of the most significant interventions on the troubled relationship between ideology and aesthetics occur in the journal. Moreover, it is in this very pragmatic context that the political efforts of the journal to help create a "culture of the people" may be viewed in a more positive critical light.

There were in all seven "Readers' Competitions" announced in Left Review, on the following themes: "To Tell the Truth" (October 1934); "A Shift at Work" (January 1935); “An Encounter" (April, 1935); "Strike!" (July, 1935); "Criticism of Two Stories" (October, 1935); "School Days" (January, 1936); and "What Life Means to Me" (October, 1936). The editor who judged and commented on most of the competitions was Amabel Williams-Ellis, herself a founding member of the journal. Two other established writers were also invited to join as guest editors - the competition on "Strike!" was judged by Sylvia Townsend Warner, while James Hanley was asked to choose from the best of the "School Days" contributions. ${ }^{17}$

In their introductions announcing the topic for the subsequent competition, one can discern perhaps little difference in the basic critical stance taken by each of the editors. Thus, for instance, they all emphasize the importance of the formal qualities of the writing they are looking to publish, rather than promoting any particular party-line orthodoxy in political content. This recommendation was, however, at the time clearly not regarded as purely a question of personal aesthetic preference, but quickly became one of the main bones of ideological contention in the pages of the journal. Indeed, the conflict emerges almost from the outset, beginning with the statement of the Writers' International itself, published in the first number of Left Review, which claimed "Journalism, literature, the theatre, are developing in technique while narrowing in content."' 18 Commenting on the radical language experimentation of writers like Joyce and Blake, Williams-Ellis herself makes the following critical reservation in her own introduction to the first competition:

This then is the proposition that I want to lay before the reader, that because our content is new we must be all the more careful of our form; that we shall be better understood if we make such innovations as we need to make, gradually. I am not suggesting for a moment that to suit our new content technical and verbal innovations will not have to be made. They will; they should be made. ${ }^{19}$

The debate about the supposed dichotomy between innovative form and 
revolutionary content continued to surface in Left Review and it is was on this central issue that much of the criticism of the journal was to be focused. However, at least in the early stages of its existence, an aesthetic appreciation of the text prevailed over those who claimed that "There is no clear line" in the journal. ${ }^{20}$ It is significant in this context to note that in announcing the competition in literary criticism in October 1935, the same non-prescriptive standpoint is once again taken: "The man who places a work according to its manifest revolutionary content, leaves the real work of criticism untouched."21 Moreover, as late as May 1936, in selecting items for publication in the "School Days" competition, James Hanley not only listed the three main criteria for good writing which had influenced his own choice: "clarity, simplicity, and sensuousness." More specifically, he also felt the need to admit that "I ruled out definitely propagandist matter, for the essence of this competition was a reflection upon childhood days, and nothing else."22

Of all the editors, it is Sylvia Townsend Warner who advocated a more pronounced political approach to literature, even though she also plays down a preference for overt revolutionary propaganda. It is perhaps indicative of the ideological confusion surrounding the question of aesthetic criteria in the journal as a whole that the competition on literary criticism, which Townsend Warner herself judged, produced in fact a poorer response among readers compared to the others - only seven entries being sent in. In her comments on these contributions, Townsend Warner once again stressed the need for a close reading of the text itself: "Attentiveness which is the first essential in criticism," a quality which, one might add, all three editors certainly apply to their individual judgement of the entries. However, in contrast to the others, Townsend Warner also emphasized a broader political view of the function of criticism, the concerns of which go beyond the text itself:

A literary critique is not merely concerned with literature. As literature is concerned with living, its criticism must have a life interest also, must express an outlook on behaviour and social conditions. And the work of art is a good training-ground for the critical faculty since the subject of the critique stays put - which is more than life does; thus giving the critic the advantage of being able to stroll round his subject and survey it from all sides instead of having to run along trying to keep pace with it. ${ }^{23}$

In the second half of this article I want to look more closely at the set of critical critieria which underpinned the different editors' reading of the contributions, in particular what they pick out as representing the main strengths and weaknesses of the winning entries. This is also of broader ideological significance since, as has been noted, the function of the competitions themselves became a subject of some heated debate, especially in the early years of the journal.

Gustav Klaus argues in his essay (1976) on Socialist fiction in the 1930s 
that the development of a genuine tradition of working-class writing was hampered by the more pressing needs of the political struggle: "the fight against Fascism was spelt with a capital 'F,' the worker-writer with a small 'w.'" There were nevertheless, according to Klaus, some notable exceptions:

The first and probably most important was a series of competitions, each on a given theme ... run by Left Review which encouraged workers to describe their work conditions. ${ }^{24}$

However, restating the criticism levelled by Alick West in the pages of Left Review soon after the first competition had been held, Klaus agrees that "the whole enterprise (with Amabel Williams-Ellis telling the workers to avoid the use of jargon) had something patronising about it." 25 This particular accusation refers back to West's intervention at the Left Review contributors' conference held on 13 April, 1935, during which he attacked the very criteria on which Williams-Ellis's critical guidance was based. In her recommendations to writers contributing to the journal on the theme of "A Shift at Work," Williams-Ellis had stressed the sensual nature of good writing. This is a key passage in understanding the subsequent critical responses of the editors:

Once more the reader should be made to use at least four of his five senses. He must feel the smoothness of the tools, the heat or coldness of what is touched, hear the clatter of pots and pans, or the much more rhythmic beat of machinery, or if the worker is an errand boy, the sounds of traffic in the streets, the calls across the street of boy to boy, or if the worker is a miner, the strange, peculiar muffled clanks and deep-toned clatters of a mine. Then there is the smell of warm oil on a machine, or of cooking or washing, or of earth turned up by the plough. Every job has smells, sounds and sensations of touch besides heat and cold that will help to make it real to the reader. Remember that is the heart of this whole business to make the reader feel as if he or she were actually there. Remember it is the unexpected but correct word that does the trick. ${ }^{26}$

Solid, practical advice it would seem, but other supporters of the journal were clearly not so impressed. As part of the debate about the basic aims of the Writers' International, Douglas Garman for example called for a more specific political content in the journal at the expense of encouraging purely fictional writing. He condemned in particular the readers' competitions themselves as being "parochial."27 As has already been mentioned, one of the most theoretically influential critiques of the journal's creative writing ambitions came from Alick West, himself a prominent Marxist literary critic, who attacked in his conference speech the above piece of practical authorial advice provided by Williams-Ellis. While not entirely rejecting the idea of literary competitions as such, West maintained that the journal's efforts in this respect nevertheless smacked of Victorian patronage, as did the cultural rationale that went with it: "We get nothing new but something which is indistinguishable from the aes- 
thetics current at the end of the nineteenth century." At the same time, West advocated a more overtly political form of writing, in which the function of art would be directly linked to the greater goal of establishing an alternative Socialist society:

Workers are not simply individuals with five senses whose writing must touch these senses; they are creators of a new social order, and their writing a part of that creating. ${ }^{28}$

While the skepticism of West and others towards the idea of using the journal as a forum for creative writing tended to become less pronounced in the subsequent issues of the journal, the essential nature of working-class poetry and prose itself continued to be discussed on a number of occasions. ${ }^{29}$ In practice, however, it is clear that the importance of the competitions themselves begins from this stage onwards to diminish. At the same time, there was, undeniably, something in what West himself says about the critical advice sometimes given to prospective writers, especially if one considers Williams-Ellis's response to the contributions to the above-mentioned theme of a shift at work. The winning entry - "Monday Morning in the Machine Shop" by Kenneth Bradshaw - produced for example the following encomium from WilliamsEllis, which could in part also be read as a reply to West's criticism:

Kenneth Bradshaw has constantly borne in mind the particular thing to be attempted. His entry is not only excellent in itself but shows much promise. Some critics might say he is too wild and that there are too many roaring lions and claw-sharpening tigers in that metal shop. To such a critic I should reply that the too generous writer, who throws his weight and his comparisons about and exaggerates an effect, will always be able to improve his later work by cold-blooded blue pencilling ... Bradshaw forges his hot impressions into images that are remembered. ${ }^{30}$

The passage from the entry to which Willams-Ellis is specifically referring is however so full of animal metaphors and overworked onomatopoeic wordplay as to appear almost parodic. Moreover, the overall impression of the text is not just figuratively problematic. While the setting of the machine shop is stereotypically compared to that of a jungle, the workers themselves are implicitly tainted by the same collectively brutish configuration as they "troop in, and take up their positions by their machines" and the shop floor bursts into a cacophony of screeches and calls:

The vast forest of belts is whizzing, and in this forest the machines make noises like wild animals. Some trumpet like panic-stricken elephants. Others whine in heightening crescendos, subside, and begin whining again like love-sick, fighting tom-cats of the night. Some whinny like horses before horror. Others whine sadly like dogs scratching on the door to get in out of the rain. Many go pop-pop-pop, laughing unholily like hysterical hyenas with hiccups. Others gibber and chatter shrill like tree-top monkeys. Some sound as if ten thousand tigers were 
sharpening their claws on sand-stone. And over all, in this vast moving jungle of belts, sounds a dull roaring as of forest lions who roar and have forgotten how to stop. ${ }^{31}$

Despite West's criticism, Williams-Ellis nevertheless continued to respond in her evaluations of the later competitions with the same positive eye for sensuous detail, praising the ability of the winning writer to produce a feeling of being there. Her close reading of the published entries all follow this line of tangible aesthetic appreciation, at the expense of the political content of the story, a critical approach which underpins the judgement passed for instance on the entries to the competition on "What Life Means to Me," published in December 1936:

We have passed over some entries that showed more signs of political activity than these, not because that is not of the first importance, but because writing, as such, must convey the sensation of living as well as its content. ... Writing is the essence of experience; the product, not the raw material.32

As has already been noted, James Hanley, one of the guest editors, also puts the stress on the importance of physical detail when he includes "sensuousness" as one of his own three key criteria in judging the competition on "School Days." However, Hanley admits to having been rather surprised at finding such manifest qualities in the contributions he read. Hanley's own critical underestimation of the creative potential of the journal's readership is in itself somewhat remarkable, given his own background as a Liverpool ex-seaman and later celebration as a writer of the vibrant oral culture of the working class. ${ }^{33}$ Despite his prime literary concerns, Hanley, like West, nevertheless chooses also to link this emergent literary talent to the hope of a future, more dynamic involvement of the working class in politics as well as literature:

One got some very startling pictures of working-class life; and, indeed, these pictures were always accompanied by a certain thrill and admiration, too, in discovering how well so many working people can express themselves, and pointedly, too "upon the state of things." It augurs well. ${ }^{34}$

In the competition on "Strike!" which was judged by Sylvia Townsend Warner, the political aspects of the contributions become, not unexpectedly, more of a central critical concern, something which is made clear from the outset. However, the moral persuasiveness of the text is once again seen to be mainly connected, not with its intellectual, but emotional impact on the reader: Those who write on such a subject will naturally write propaganda; that is desired. But it will be useful to see how far competitors can do the best sort of propaganda: that which does not simply state facts and arguments, but drives facts and arguments into readers' minds, rouses their feelings, excites them, by showing the human tension, the clash of drama in this side of the struggle of the working class. 35

The critical feedback on the above theme was also, curiously enough, 
given in the form of yet another competition. Readers were invited to write a literary critique of two of the entries - "Strike" by B. J. Green and "Strike Action" by D. J. D. - the first of which had been judged as the winning short story. In her own response to both these stories and the readers' critical appraisals of them, Townsend Warner reiterates the importance of "attentiveness" to the text and of "critical acuteness," 36 despite her own previous pronouncements on the extended political function of criticism. The winning critique itself, written by John Maginnis, is also later singled out by Townsend Warner for its successful implementation of such close-reading skills. However, it is significant too that John Maginnis's winning entry on criticism of the second story - "Strike Action" - returns to the controversial issue of formal experimentation, the use of which, he claims, would alienate a prospective working-class readership:

$\ldots$ the form which the author uses - that of psychological analysis - obscures the issues of the story for the average reader. And it is the average reader that proletarian writers in the long run wish to reach. This form is too involved and subtle for use in a very short story. It pays too much attention to small psychological details, diffusing the reader's sympathies, and prevents a vivid impression of the whole scene. To sum up, the content is good, but the form in which it is expressed is not the most suitable to get the values across. ${ }^{37}$

It is certainly true that the story "Strike Action" contains a more ambitious use of form, in particular the convincing psychological insight into family tensions during a strike which the reader gains through the dialogue, some of which is in Welsh dialect:

“"Ow will they know now up there - p'raps they migh' think you kept away on purpose an' stop you for good," said the anxious wife.

"Aye," broke in Sam, the eldest son, "p'raps it'tud be better if you went up to see 'em now - if you 'urried you migh' catch 'em before they leave the office."

"Aye, where's my boots?"

"Isn't it a shame," she cried in exposulation, "a man who is entitled to work - can't go - mustn't go, ach-y-fi-it makes 'ou feel I don't know."38

However, compared to the winning story "Strike!," which ends with a dramatic political change of heart on the part of a striker's - previously skeptical - wife, there is a total avoidance in "Strike Action" of the same facile political didacticism, often associated with the worst aspects of Socialist Realism. Indeed, this latter point was also something which another contributor to the competition in criticism specifically raised in relation to the winning story:

The plot is faintly reminiscent of the typical "proletarian" story made up of mechanical abstractions taken from the text-book who, at the given stimulus, automatically respond, "You are 
quite right, Bill. I am going to join the Communist Party, as it is the only party fighting back against the bosses' offensive." 39

It is, nevertheless, indicative of the direction of the aesthetic debate within the journal that in the last two competitions on "What Life Could Mean to Me" and "On Taking Politics Seriously," the prescriptive element of propaganda becomes more predominant and the sensuous use of language, celebrated by Williams-Ellis and James Hanley, is evidently not held in the same high regard. This, moreover, is not an isolated phenomenon, but forms part of the shift in political emphasis of the whole journal itself, which from 1936 onwards became more ideologically geared both to the fight against Fascism in Spain, as well as to a more unequivocal support of the Soviet Union. This development had of course a direct impact on the journal's aesthetics, reflected in a concomitant move away from creative fiction to that of documenting facts, as is clearly indicated in the competition announcement on the theme of "What Life could Mean to Me":

The object of our competition this month is not only to give opportunities for skill and selection in handling facts, but also to provide documents of value which will be interesting and worth preserving. It is an experiment in extending the field of "social realism" which we try and make a keynote of our literature and discussions in these pages. ${ }^{40}$

However, it is also significant that not only were no entries ever published on this particular theme, the gap in announcing the next competition, "On Taking Politics Seriously," was a much longer one - from April 1937 to January 1938. It is obvious that the journal had by then more or less given up on its earlier efforts to encourage working-class readers to write creatively of their own daily experiences. Instead, the editors turned their attention to what they saw as the more pressing ideological exigencies of the day - typified by a special issue devoted entirely to celebrating the 20th anniversary of the Soviet Union. Here for instance, in a panegyric survey of Soviet arts, John Lehmann propounded the need for both close critical conformity and the celebration of the collective epic as part of a cultural united front against the growing threat to Socialism:

The outbreak of fresh wars and revolutions, the activity of Socialism's enemies within the borders of the Soviet Union as well as outside, seem to me more likely to make significant the idea of Socialist Realism than any amount of critical diatribes, and to bring Soviet art back once more to its central path: Epic. ${ }^{41}$

Thus, by this stage, a "reductive vision of literature," as David Margolies describes it, had finally won over those "democratic attitudes" of editors like Williams-Ellis, which had formed the cultural motivation behind the original launching of the journal. 42

In an interview with John Lucas, Edgell Rickword, who had been another of the main editors of Left Review during its existence, reiterated that the prime 
purpose of the journal was in fact to encourage working-class writing: Certainly, that was basically the thing we most wanted to do. We didn't want to fill the pages with our own stuff ... It seemed reasonable to imagine that there must be a good deal of work painfully written out on old school sheets, old school books, exercise books. ${ }^{43}$

Rickword goes on however to identify more specifically the cause of the journal's demise both with the increasing lack of readers' literary contributions and the poor quality of that which was sent in: "I'm forced to admit that much of it was very bad ... And why we stopped the Review. We couldn't get work of the quality that would have justified us carrying on." 44 This is a rather curious rationalisation of the reasons for the closure of Left Review in the light of the remarkable ease in which John Lehmann himself had in discovering new working-class talent for his own "non-political" literary journal New Writing, a publication which lasted from 1936 to $1950 .{ }^{45}$ Moreover, also in contrast to Rickword, Lehmann later recalled what he describes as the "flood of manuscripts" that constantly arrived at his office during this time. ${ }^{46}$ But perhaps one of the reasons for this flow of quality working-class writing lies elsewhere. Despite his naive comments above about the superiority of Soviet epic realism, in his role as editor of New Writing Lehmann was not as politically prescriptive in his choice of texts and this, it could be argued, lay behind the success of his own journal and the ultimate failure of Left Review. 47

Although Rickword also claims that "there weren't any great pressures from the party to make us toe a conforming line," 48 it emerges from an overall examination of the development of the journal that the political orientation certainly did become more orthodox Stalinist, particularly after the outbreak of the Spanish Civil War in 1936. While contributions tended more and more to come from established Communist writers and critics, the articles themselves became more internationally - pro-Soviet - oriented. The number of book reviews also increased, often being used as a forum for crude Stalinist propaganda. ${ }^{49}$ More significantly in terms of the encouragement of creative writing among its working-class readers, the literary competitions, which had started out as one of the cultural showpieces of the journal, lost their central role, as the subjects covered became more overtly politicized and factual.

This shift in the cultural concerns of the journal can in many ways be linked to a much wider ideological debate within the international Communist movement as a whole. By 1936, the revolutionary Red front of the so-called Third Period in the Soviet Union had been replaced by the clearly less overtly proletarian politics of the Popular Front. This had a direct impact on the cultural orientation of the Communist Parties outside the Soviet Union - as well as the journals associated with them. There is a parallel here to the situation in the United States, where the cultural aims of the American Communist Party fol- 
lowed as similar political trajectory. According to Alan M. Wald, the change in Communist political strategy had by 1936 a profound effect on both the "styles, themes, and organizational forms" of Left cultural workers in America:

The most famous correlation has concerned the differentiation between the pre- and post-Popular Front era in the Thirties. In the first half of the decade (actually, starting in 1928), the emphasis was on working-class literature, revolutionary ideology, and creating venues to give voice to unknown cultural workers from the plebeian classes. In the second half of the decade, the emphasis was on the creation of a people's democratic literature, anti-fascist ideology, and the development of organizations and conferences with well-known and successful writers. ${ }^{50}$

Another important factor in explaining the re-orientation of journals like Left Review, away from working-class writing, was the increased emphasis on Socialist Realism in the Soviet Union after the 1934 Soviet Writers Congress. Although this conference was primarily directed towards Soviet cultural workers, the message also percolated through to Party activists in the West. In the debate about art or propaganda, which developed in the wake of the conference, the growing emphasis on Socialist Realism had, as Barbara Foley has shown, also sociological implications for Communist cultural practice everywhere. Once again, it was the writers from working-class backgrounds who were pushed to the margins in the drive for political and cultural orthodoxy:

... there was no necessity for the authors of socialist realist texts to come from the ranks of the proletariat. Professional middleclass writers who were sympathetic fellow travelers were as well equipped - indeed, in technical terms, usually better equipped to represent emergent national reality. 51

It is clear therefore that the aesthetic policies of Left Review, despite its initial enthusiasm for working-class writing, were more bound up with the overall international political scene than have previously been noted. It is, however, difficult to know precisely how much direct influence the British Communist Party exerted on the editorial practices of the journal itself. 52 But since most of its editors were also active members of the Party, it is not surprising that the journal reflected the more overriding policy shifts in the international Communist movement, not least within the sphere of culture. Nor it is strange that as its pro-Soviet politics became more intrusive, its function as a broad forum for working-class culture was taken over by such less overtly ideologically oriented journals as John Lehmann's New Writing.

In an advert added to the end of the valedictory editorial in the final issue of Left Review, the editors made the claim that the "volumes of Left Review will undoubtedly be of considerable historic interest in years to come. For they contain the first fruits of a new kind of writing, a new cultural direction." 53 As this article has tried to show, in retrospect this proved to be a literary enterprise fraught with contention about the relationship between ideology and art, poli- 
tics and literature. However, despite the politically compromised critical debate which characterized its later years, it was nevertheless in the practical encouragement of creative writing that the journal stands out as being perhaps most successful and challenging, both in the working-class writers that appeared in its pages and in the unique opportunity for critical guidance it offered to prospective reader-writers.

This debate about working-class writing still continues today of course. For example within the vibrant framework of the Federation of Worker Writers and Community Publishers in Britain, whose local group writing activities and publications have maintained a broad and solidly popular appeal ever since its emergence in the 1970s. In their own survey of the cultural significance of this new dynamic trend in modern working-class writing, Dave Morely and Ken Worpole consciously locate the origins of today's movement in a tradition that includes both New Writing and Left Review. While they themselves are critical of the latter journal's "centralised and commissioning point of view," 54 they nevertheless recognize that Left Review remains an important forerunner in the struggle for working-class people to find a literary voice of their own. It is perhaps only now that its unique cultural contribution to this ongoing democratic process is finally being recognized and fully appreciated.

I The Left Review, Vol. 3, (May 1938). (Reprinted London: Frank Cass, 1968); Vol. 8, (May, 1938), 957. All future references are to this facsimile reprint of the complete journal.

2 Ibid.

3 George Orwell, The Road to Wigan Pier (Harmondsworth, 1972), 146.

4 Julian Symons, The Thirties: A Dream Revolved (London, 1975), 74

5 Ibid.

${ }^{6}$ Samuel Hynes, The Auden Generation: Literature and Politics in England in the 1930s (London, 1992), 152.

7 Bernard Bergonzi, Reading the Thirties: Texts and Contexts (London, 1978), 135.

8 Adrian Caesar, Dividing Lines: Poetry, Class and Ideology in the 1930s (Manchester, 1991), 204.

9 Terry Eagleton \& Drew Milne, Marxist Literary Theory: A Reader (Oxford, 1996), 103.

10 David Margolies, "Left Review and Left Literary Theory" in Jon Clark et al., eds., Culture and Crisis in Britain in the 30s (London, 1979), 71.

11 Valentine Cunningham, "Neutral? 1930s Writers and Taking Sides" in Frank Gloversmith, ed., Class, Culture and Social Change: A New View of the 1930s (Sussex, 1980), 46. 
12 Valentine Cunningham, "The Age of Anxiety and Influence; or, Tradition and the Thirties Talents" in Keith Williams \& Steven Matthews, eds., Rewriting the Thirties: Modernism and After (London, 1997), 15.

13 Maroula Joannou, "Sylvia Townsend Warner in the 1930s" in Andy Croft, ed., $A$ Weapon in the Struggle: the Cultural History of the Communist Party in Britain (London, 1998), 91.

14 Ibid, 92.

15 E.P. Thompson, "Left Review" in Persons \& Polemics: Historical Essays (London, 1994), 231.

16 David Margolies, Writing the Revolution: Cultural Criticism from Left Review (London, 1998), 231.

${ }^{17}$ Both Amabel Williams-Ellis and Sylvia Townsend Warner were active members of the British Communist Party. Williams-Ellis was also part of the British delegation to the Soviet Writers' Congress on Socialist Realism in 1934, about which she wrote enthusiastically in the very first issue of Left Review, October, 1934, 17-28.

${ }^{18}$ Left Review, Vol. 1, (October, 1934), 38. In the ensuing controversy, Lewis Grassic Gibbon, the Scottish novelist, wrote for instance that: "It is nonsense to say that modern literature is narrowing in 'content'; there was never in the history of English letters such a variety of books on such a variety of subjects, never such continuous display of fit and excellent technique. One need do no more than glance through an issue of The Times Literary Supplement to be convinced of this." Ibid, 179.

${ }^{19}$ Left Review, Vol. 1, (October, 1934), 40.

${ }^{20}$ See, for example, Montagu Slater, "The Purpose of a Left Review" in Left Review, Vol. 2, (June 1935), 359-365.

${ }^{21}$ Left Review, Vol. 3, (October, 1935), 33.

22 Left Review, Vol. 4, (April, 1936), 305.

${ }^{23}$ Left Review, Vol. 3, (January, 1936), 178.

24 H. Gustav Klaus, "Socialist Fiction in the 1930s: Some Preliminary Observations in Renaissance and Modern Studies, Vol. XX, (1976), 21.

25 Ibid.

${ }^{26}$ Left Review, Vol. 1, (December, 1934), 74.

${ }^{27}$ Left Review, Vol. 1, (February, 1935), 181.

${ }^{28}$ Left Review, Vol. 2, (June, 1935), 368. West's attack on working-class sensualism in writing is in contrast to his celebration of the very same literary quality which he found in Harold Heslop's proletarian novel The Gate of a Strange Field. In the final chapter of Crisis and Criticism, which deals with this work, West compares Heslop's style of writing with that of James Joyce: "In spite of the difference in the relative gift of language, life in Heslop's novel has a warm, bodily reality which Joyce, cut off from the social experience that makes life such, cannot create. The differences in the descriptions of the human body by 
the two authors illustrate this." Crisis and Criticism, (London, 1937), 185. It is noteworthy that this last chapter was removed at West's behest from the 1975 reprint of the work.

${ }^{29}$ See, for example, the "Controversy" debate which developed about the aims of the Writers' International in the December, 1934, and February, 1935 issues.

${ }^{30}$ Left Review, Vol. 1, (March, 1935), 217-18.

31 Ibid, 200.

32 Left Review, Vol. 5, (December, 1936), 826.

33 See, for example, his portrayal of seamen in Boy (1931) and his classic account of working-class family life in The Furys (1935).

${ }^{34}$ Left Review, Vol. 4, (April, 1936), 306. At the contributors' conference of 1935, the novelist John Sommerfield suggested that responses of this kind smacked of both paternalism and political sectarianism: "My own strongest criticism of the LEFT REVIEW is that it shows sometimes a sort of 'snootiness,' as if to say 'Isn't it marvellous that the workers should be able to write at all?"' Left Review, Vol. 2, (June, 1935), 367.

${ }^{35}$ Left Review, Vol. 2, (June, 1935), 411.

${ }^{36}$ Left Review, Vol. 3, (January, 1936), 78.

37 Ibid, 179.

38 Ibid, 30.

${ }^{39} \mathrm{Ibid}, 178$.

${ }^{40}$ Left Review, Vol. 6, (April, 1937), 176.

41 Left Review, Vol. 7, (November, 1937), 581. John Lehmann was a Bloomsbury poet and literary editor who gravitated towards Communism in the 1930 s, but who later joined the ranks of intellectual apostates who reneged on their earlier radical commitment. See for example Lehmann's own, highly revisionist autobiographical account of the 1930s, The Whispering Gallery (London, 1955).

42 Margolies, Writing the Revolution, 186.

43 John Lucas, "An Interview with Edgell Rickword" in Renaissance and Modern Studies, Vol. XX, (1976), 44.

44 Ibid.

45 In a full-page advert for New Writing, published in Left Review, Vol. 4, (May, 1936), 394, Lehmann's own journal is described as "A new half-yearly collection of the imaginative work of the younger authors of today. Literary and nonpolitical, though definitely anti-fascist in outlook." In his autobiography, The Whispering Gallery, Lehmann later recalled: "In Left Review the politics came, fatally, first; I wanted a magazine in which literature came first, with the politics only as an undertone." 232.

46 John Lehmann \& Roy Fuller, "Introduction" to The Penguin New Writing, (Harmondsworth, 1985), 11.

${ }^{47}$ Another contributing factor might have been the focus of the journal on fic- 
tion only and the total absence of critical debate. As was stated in the opening number: "New Writing will appear twice yearly, and will be devoted to imaginative writing, mainly by young authors. It does not intend to concern itself with literary theory, or the criticism of contemporaries." New Writing, No. 1, (Spring, 1936).

48 Lucas, "Interview with Edgell Rickword," 13.

49 See for example R.F. Andrews, "Leninism Trotskified" in Left Review, Vol. 6, (June, 1937), 291-8; J.R. Campbell, "Trotsky's 'Explanations"” in Left Review, Vol. 8, (December, 1937), 685-8.

50 Alan M. Wald, "The 1930s Left in US Literature Reconsidered" in Writing from the Left: New Essays on Radical Culture and Politics, (London, 1994), 109.

51 Barbara Foley, Radical Representations: Politics and Form in U.S. Proletarian Fiction, 1929-1941, (Durham, N.C., 1993), 163.

52 Edgell Rickword, who was himself both a member of the Communist Party and one of the founding members of Left Review, recalled that: "Well, naturally I was a supporter of the communist side. By then I was a party member, you see, and was doing Branch work, propaganda, and the editors of the Review had fairly regular meetings with party high-ups. We came in for some mild criticism for not giving the right emphasis here or there, no more than that." Lucas, "Interview with Edgell Rickword," 9.

${ }^{53}$ Left Review, Vol. 8, (May, 1938), 960. Another contributing factor might have been the focus of the journal on fiction only and the total absence of critical debate. As was stated in the opening number: "New Writing will appear twice yearly, and will be devoted to imaginative writing, mainly by young authors. It does not intend to concern itself with literary theory, or the criticism of contemporaries." New Writing, No. 1, (Spring, 1936).

${ }_{54}$ Dave Morely \& Ken Worpole, eds., The Republic of Letters: Working Class Writing and Local Publishing, (London, 1982), 69. 